\title{
Szpiedzy i szpiegostwo w prasie poznańskiej okresu dwudziestolecia międzywojennego
}

11 listopada 1918 r. w Warszawie świętowano niepodległość, tymczasem w Poznaniu ciągle obecne były wojska niemieckie. Niemcy, choć w ogólnym rozrachunku wojnę przegrały, nie były gotowe do rezygnacji z terenów dawnego zaboru pruskiego, a także Śląska, Warmii i Mazur. Mieszkańcy wymienionych obszarów trwali w gotowości, dla nich walka się nie skończyła. Warto podkreślić, że poznaniacy nie dowierzali, że marszałek Józef Piłsudski nie zrezygnował z ziem zachodnich. Tymczasem on żywo interesował się sytuacją w Poznańskiem, na bieżąco otrzymywał raporty o działaniach w dzielnicy, znał też nastroje Wielkopolan, zarówno pełne obaw oczekiwanie, jak i wątpliwości wobec oficjalnej postawy naczelnego wodza ${ }^{1}$.

27 grudnia rozpoczęły się walki w Poznaniu. Zwycięska insurekcja pozwoliła Polakom z ziem zachodnich stać się częścią niepodległej Rzeczypospolitej. Konsolidowanie wszystkich terenów wchodzących w skład restytuowanego państwa polskiego przebiegało w cieniu problemów wewnętrznych i niestabilnej sytuacji zewnętrznej. Borykano się nade wszystko z odrębnościami między poszczególnymi regionami Rzeczypospolitej, dotychczas podlegającymi trzem różnym porządkom prawnym, ekonomicznym i politycznym. Normalizację sytuacji w państwie utrudniało zaangażowanie kraju w kolejne wojny: z Rosją bolszewicką i Zachodnioukraińską Republiką Ludową, w konflikt z Litwą. Sytuację komplikowały dodatkowo roszczenia Republiki

\footnotetext{
${ }^{1}$ Archiwum Instytutu Józefa Piłsudskiego w Ameryce, kol. Adiutantura Generalna Naczelnego Wodza, teczka: Listopad-Grudzień 1918, sygn. 701/2/1, Raport sytuacyjny z Poznania, s. 48; Sprawozdanie z sytuacji polityczno-wewnętrznej w zaborze pruskim, s. 171-176; Meldunek z Poznania, s. 177; http://www.pilsudski.org/archiwa/teczka.php?nonav=0\&nrar=701\&nrze sp=2\&sygn=1 (dostęp: 28 kwietnia 2015 r.).
} 
Weimarskiej wobec Polski. Rola ziem zachodnich w II Rzeczypospolitej była wyjątkowa, stanowiły one bufor oddzielający państwo polskie od Niemiec. Roszczenia niemieckie wobec Polski, nieuznawanie niezmienności granicy wschodniej Rzeszy, permanentna penetracja terytorium poznańskiego przez wywiad niemiecki, wymuszały na Polakach konieczność wypracowania działań obronnych ${ }^{2}$. Wywiad niemiecki prowadził działania na obszarze całego państwa, jednak w ramach podejmowanego tematu zajęto się jedynie województwem poznańskim ${ }^{3}$.

Poznań był siedzibą Dowództwa Okręgu Głównego Sił Zbrojnych w byłej dzielnicy pruskiej. Struktury służby informacyjnej, która funkcjonowała już w ramach Polskiej Organizacji Wojskowej zaboru pruskiego, a także jako komórka Stronnictwa Narodowo-Demokratycznego, ulegała kolejnym zmianom. Ze struktur POW powstał kontrwywiad wojskowy podlegający wspomnianemu Dowództwu Okręgu Głównego Sił Zbrojnych w byłej dzielnicy pruskiej (Wydział Informacyjny Ic). Jednym z jego zadań była ochrona przeciwszpiegowska. Dynamiczna sytuacja odradzającego się państwa wpłynęła na organizację kontrwywiadu, do końca wojny polsko-bolszewickiej nazywanego defensywą. W okresie przejściowym dla ziem zachodnich dawnej Rzeczypospolitej, a więc od przedłużenia pokoju między aliantami a Niemcami $\mathrm{w}$ Trewirze 16 lutego, do podpisania porozumień pokojowych 28 czerwca 1919 r. w Wersalu, kiedy ostatecznie przyznano Wielkopolskę Polsce, struktury wywiadu ofensywnego i defensywnego dostosowywano do bieżących potrzeb. Po zawarciu pokoju wersalskiego funkcjonujące dotąd Dowództwo Okręgu Głównego zostało przemianowane na Dowództwo Okręgu Generalnego Sił Zbrojnych w Poznaniu, podlegające Sztabowi Generalnemu Wojska Polskiego. Kontrwywiad prowadził Wydział II Dowództwa Okręgu Generalnego, który w 1924 r. otrzymał nazwę Samodzielnego Referatu Informacyjnego Dowództwa Okręgu Korpusu nr VII ${ }^{4}$. Od 1921 r. pracę poznańskiego kontrwywiadu wspierała utworzona zarządzeniem ministra spraw wojskowych jako jedna z trzech powołanych wtedy w kraju ekspozytura nr III w Poznaniu przy II Oddziale Sztabu Generalnego WP. Samodzielny Referat Informacyjny przy DOK nr VII pro-

2 J. Krasuski, Polska-Niemcy. Stosunki polityczne od zarania po czasy najnowsze, Poznań 2003, s. 224-227, 248-250.

${ }^{3}$ Wprowadzony 2 sierpnia 1919 r. podział administracyjny zasadniczo został zachowany do 1937 r., ówczesne (z lat 1923-1937) zmiany przebiegały w obrębie ustalonych w 1919 r. granic województwa. Zmiana granic Poznańskiego wprowadzona została w 1937 r., obejmowała powiaty nadnoteckie, które zostały wyłączone z woj. poznańskiego i włączone do woj. pomorskiego. Jednocześnie z woj. łódzkiego do poznańskiego włączono powiaty: kaliski, koniński, kolski i turecki. Przyjęty w 1937 r. podział administracyjny odpowiadał podziałowi terytorialnemu administracji wojskowej (tu: DOK VII i DOK VIII), zob. A.J. Mielcarek, Podziaty terytorialno-administracyjne II Rzeczypospolitej w zakresie administracji zespolonej, Warszawa 2008, s. 38-39, 59.

${ }^{4}$ A. Pepłoński, Kontrwywiad II Rzeczypospolitej, Warszawa 2002, s. 18. 
wadził działania kontrwywiadowcze wewnątrz kraju, a ekspozytura nr III realizowała zadania z zakresu wywiadu płytkiego i kontrwywiadu zaczepnego na terenie Niemiec ${ }^{5}$. Samodzielny Referat Informacyjny współpracował z takimi organami, jak Policja Państwowa, Korpus Ochrony Pogranicza itp. ${ }^{6}$

Działania polskiego kontrwywiadu na obszarze Poznańskiego nadal pozostawiają wiele niewyjaśnionych wątków. Powodem jest nie tylko specyfika działań kontrwywiadowczych, lecz nade wszystko stan archiwów polskich służb specjalnych z okresu międzywojennego. Wybuch wojny w 1939 r., chaos pierwszych dni, spowodowały, że utracono większą część archiwów polskiego wywiadu. Część zasobów znalazła się w posiadaniu Niemców i Sowietów, część została celowo zniszczona przez Polaków. Zachowane materiały z działań II Oddziału są więc rozproszone ${ }^{7}$. Z pozostałych dokumentów najwięcej informacji na temat działań kontrwywiadu odnaleźć możemy w zbiorach Centralnego Archiwum Wojskowego i Archiwum Akt Nowych. Historię działań wywiadu defensywnego znamy dzięki opracowaniom m.in.: Andrzeja Pepłońskiego, Andrzeja Misiuka, Tadeusza Dubickiego ${ }^{8}$. Poznański kontrwywiad nie stanowił dotąd przedmiotu odrębnych badań ${ }^{9}$, zagadnienia działań tutejszej placówki kontrwywiadowczej stanowią jedną z niemal nieznanych kart historii. Przedmiotem przedstawianego tekstu także nie jest cała działalność poznańskiej „Dwójki”, a jedynie jej rola w uświadomieniu zagrożenia szpiegostwem ludności cywilnej na terenie województwa poznańskiego, a także rola, jaką odegrała prasa Poznańskiego w realizacji tego zadania.

Wspólny front walki z obcą dywersją zbudowano, gdy formalnie Wielkopolska należała do Cesarstwa Niemieckiego, wybuch powstania wielkopolskiego szybko zmienił położenie poznańskich konspiratorów. Sztab Generalny WP w Warszawie na bieżąco wydawał rozkazy dotyczące organizacji służby informacyjnej i przeszkolenia kolejnych rodzajów broni w jej zakresie. Rozkaz dzienny z 2 lutego 1919 r., pochodzący z Dowództwa Głównego Sztabu Generalnego WP w b. dzielnicy pruskiej ogłaszał postanowienie Naczelnej Rady Ludowej (NRL) w Poznaniu, które w zakresie działań wywiadowczych okre-

5 Tamże, s. 18.

${ }^{6}$ Tamże, s. 39.

7 A. Pepłoński, dz. cyt., s. 8-9; P. Cichoracki, D. Dąbrowski, Wykaz akt Oddziału II Sztabu Głównego Wojska Polskiego i jego Ekspozytur z lat 1918-1939 przechowywanych w Wydziale IV Biura "C" Ministerstwa Spraw Wewnętrznych, [w:] Wywiad i kontrwywiad wojskowy II RP, t. IV, pod red. T. Dubickiego, Łomianki 2014.

${ }^{8}$ Zob. m.in.: A. Misiuk, Stużby specjalne II Rzeczypospolitej, Warszawa 1998; Wywiad i kontrwywiad II RP, t. 1-4, pod red. T. Dubickiego, Łomianki 2010, 2012, 2013, 2014.

${ }^{9}$ Cz. Partacz, B. Polak, Wywiad i kontrwywiad formacji wielkopolskich 1918-1919. Postulaty badawcze, [w:] Kontrwywiad II RP (1914) 1918-1945 (1948), t. 1, pod red. Z. Nawrockiego, Warszawa 2013, s. 45; M. Polak, Wspótdziatanie spoteczeństwa polskiego z wywiadem i kontrwywiadem II Oddziatu SG w Wielkopolsce w latach 1938-1939. Postulat badawczy, [w:] Kontrwywiad II RP (1914) 1918-1945 (1948), t. 1, dz. cyt., s. 256. 
ślało, że służbą odpowiedzialną za ochronę przed szpiegostwem była Policja Państwowa, to z jej funduszu pokrywano konieczne wydatki związane $\mathrm{z}$ realizacją zadań $\mathrm{w}$ podanym zakresie. W przypadku braku wystarczających funduszy NRL deklarowała zapewnienie ich. Służbę wywiadowczą wojskową pozostawiono w rękach kpt. Antoniego Floriana Seydy, a więc przy Sztabie Generalnym (ściślej w ramach D.O. Głównego Sztabu Generalnego WP). Jednocześnie zabroniono formowania innych tajnych służb i formacji niż określone $\mathrm{w}$ rozkazie ${ }^{10}$.

Patriotyzm Polaków, mieszkańców ziem zachodnich, nie okrzepł po odzyskaniu niepodległości, nadal upatrywali oni głównego zagrożenia za zachodnią granicą, często nawet wbrew sugestiom „Dwójki” forsowali konieczność stałej gotowości wobec zachodniego sąsiada. Nadmierne skoncentrowanie prasy poznańskiej na zagrożeniu niemieckim stało się przedmiotem pisma wystosowanego do Adiutantury Generalnej, w którym Dowództwo Okręgu Generalnego w Poznaniu zaznaczało: „Prasa poznańska zgodnie zresztą z ogólnym nastrojem tutejszego społeczeństwa zupełnie nie odpowiada powadze chwili i nie odzwierciedla nastrojów panujących w reszcie Polski [...]. W tutejszej prasie jednak uciera się pogląd, że niebezpieczeństwo niemieckie jest większe niż bolszewickie, a tytuły w dziennikach brzmią »więcej na zachód mniej na wschód «. Inspirowanie prasy w kierunku zmiany tego poglądu nie odnosi skutku"11. W celu zmobilizowania poznańskich redaktorów do współpracy w okresie wojny polsko-bolszewickiej Biuro Propagandy Prasowej DOGen. Poznań przekazało List otwarty, w którym wspominało o bolszewickim potencjale propagandowym, który całą swoją prasę przeznaczył do zamieszczania informacji antypolskich ${ }^{12}$. Jako odpowiedź na ich działania proponowano, aby poznańscy redaktorzy przyłączyli się do działań prasy w kraju i zamiast publikować powieści popularne, rozpoczęli publikowanie: tekstów antybolszewickich, wspomnień osób, które doświadczyły okrucieństwa bolszewików, a także aby dołożono starań i publikowano w postaci broszurek opowiadania antybolszewickie, które można rozdać ludności cywilnej i rozpowszechniać pośród żołnierzy. Deklarowano pomoc finansową rządu dla redakcji, zdecydowanych podjąć się współpracy ${ }^{13}$.

10 Rozkazy dzienne Dowództwa Głównego Sił Zbrojnych w b. zaborze pruskim do nr. 100, 1919 r., sygn. 53-1144-1, Rozkaz dzienny nr 29 Dowództwa Głównego z dn. 2 lutego 1919 r., pkt. $1 b, \S 2 \mathrm{c})-\mathrm{e}), \mathrm{g})$.

11 Archiwum Instytutu Józefa Piłsudskiego w Ameryce, kol. Adiutantura Generalna Naczelnego Wodza, teczka: Sierpień-październik 1920, sygn. 701/2/10, „List otwarty” skierowany do wszystkich redaktorów prasy polskiej z 29 VII 1920, s. 44-45. http://www.pilsudski.org/archiwa/ dokument.php?nonav=0\&nrar=701\&nrzesp=2\&sygn=10\&handle=701.180/10762 (dostęp: 2 maja 2015 r.).

12 Tamże, s. 46-47.

13 Tamże. 
Nie tylko podczas wojny, lecz i w czasie pokoju mobilizowano do wspólnego działania. Wykorzystywano wszystkie siły i środki dla budowy świadomego zagrożeń społeczeństwa, zdolnego nie tyle rozpoznać szpiega, ile funkcjonować w państwie ze świadomością zagrożeń dla bezpieczeństwa, a także indywidualnej roli każdego obywatela w przeciwdziałaniu im.

Istotnym elementem działań była edukacja obywatelska, nie tyle patriotyczna, ile oparta o umiejętność wykorzystania otwartych źródeł informacji. Prasa Poznańskiego bez wyjątku, a zatem zarówno największe dzienniki: „Kurier Poznański”, „Nowy Kurier”, ,Dziennik Poznański”, jak również "Gazeta Szamotulska”, "Gazeta Międzychodzka” i inne, publikowały regularnie informacje dotyczące zagadnień związanych z koniecznością ochrony spraw państwa. Prasa zamieszczała kilka typów informacji dotyczących szpiegów i szpiegostwa. Pojawiały się więc informacje opisujące zagraniczne skandale, problemy obcych służb, traktowane po części jak ciekawostki z dalekich krajów, czy też zamieszczane ku przestrodze prawdziwie "mrożące krew w żyłach" historie zdrajców.

Z powagą natomiast traktowano wszelkie przejawy zagrożenia dla Rzeczypospolitej. Artykuły pojawiały się nie tylko w chwilach rozstrzygania losów szpiegów przyłapanych na popełnianiu przestępstwa, lecz również gdy postanawiano o nowych rozwiązaniach czy nawoływano do większej ostrożności w związku ze wzrostem aktywności obcych służb wywiadowczych na terytorium Polski. Nasilenie się aktywności obcych służb w państwie wzbudziło w opinii publicznej pytanie o wymiar kar za jedno z najcięższych przestępstw przeciwko Rzeczypospolitej. Łamy prasowe stały się miejscem rozstrzygania kwestii dotyczących istniejącego porządku prawnego. Przy okazji wydania wyroków w sprawach dwóch żołnierzy - por. Urbaniaka i por. Piątka, którzy oddali dokumenty dotyczące obrony Pomorza obcemu wywiadowi, redakcja „Myśli Niepodległej” zwróciła uwagę na sposób karania szpiegów ${ }^{14}$. Gazeta nawoływała do opracowania i wprowadzenia odrębnej ustawy dotyczącej kar za szpiegostwo. Wspomniano o konieczności unifikacji całego systemu legislacyjnego w Rzeczypospolitej. Kwestie kar za przestępstwa, takie jak zdrada państwa czy zdrada stanu, rozstrzygał Kodeks Karny obowiązujący tymczasowo w Rzeczypospolitej Polskiej na ziemiach zaboru rosyjskiego ${ }^{15}$,

14 Nowy etap walki ze szpiegostwem, „Myśl Niepodległa” (Warszawa), nr 860 z 9 kwietnia 1927 r., s. 229.

${ }^{15}$ Część Czwarta: Zdrada kraju, Kodeks Karny obowiąujący tymczasowo w Rzeczypospolitej Polskiej na ziemiach $b$. zaboru rosyjskiego $z$ dodaniem przepisów przechodnich $i$ ustaw, zmieniajacych i uzupetniających postanowienia karne kodeksu, odpowiednich przepisów Kodeksu Karnego Niemieckiego i Ustawy Karnej Austriackiej, obowiazzujacych w pozostatych dzielnicach Rzplitej oraz Komentarza i orzeczeń Sądu Najwyższego, oprac. W. Makowski, t. 2, cz. II-XIX K.K., Warszawa 1921, s. 50-93. 
kolejne akty prawne (w tym Kodeks Karny z 1932 r.) szeroko ujmowały sprawy najcięższych przestępstw przeciwko ojczyźnie ${ }^{16}$.

Obok troski o adekwatność kar w stosunku do win przestępców nie uciekano od komentowania wyroków czy budowania atmosfery najwyższego potępienia dla złoczyńców. I tak we wspomnianej sprawie dwóch polskich żołnierzy autor artykułu z ulgą i satysfakcją pisał o zasądzeniu kary śmierci dla obydwu, a także o tym, że prezydent nie skorzystał z prawa łaski, co oznaczało, że wyrok został wykonany ${ }^{17}$. Podobny w tonie komentarz możemy odnaleźć na łamach „Gazety Szamotulskiej”, która dokładniej jeszcze prezentowała sylwetki winowajców, zaznajamiając czytelników również z ich zachowaniem podczas rozprawy, a także tuż przed egzekucją, która - jak dowiadywali się zainteresowani - odbyła się w Forcie Żółkiewskiego na Mokrem (w Toruniu), dokąd pod eskortą zawieziono skazańców. Gazeta zwracała uwagę, że zgodnie z praktyką sądową, pierwszy poddawany był egzekucji ten, którego wina była lżejsza. Nie oszczędzono czytelnikom detali samej egzekucji. Wspominano również o pochodzeniu obydwu. Por. Piątek był synem nauczyciela seminarium nauczycielskiego, brat jego matki służył w wywiadzie niemieckim. Por. Urbaniak był synem administratora majątku Chłapowskiego w powiecie kościańskim (prawdopodobnie chodziło o majątek hr. Alfreda Chłapowskiego w Bonikowie $)^{18}$.

Silnie nacechowane emocjonalnie były doniesienia o sprawach sądowych nad polskimi obywatelami, szczególnie żołnierzami, którzy służyli obcym państwom, sprzeniewierzając się złożonej Polsce przysiędze, za nic mającym służbę ojczyźnie i narodowi. Nie starano się wzbudzić sympatii dla podejrzanych o szpiegostwo, a nierzadko ferowano wyrok przed końcem procesu. Jednym z surowo ocenianych przez opinię publiczną był kpt. Mikuła, który wraz z dwoma innymi żołnierzami współpracował z agentem Lamszą. Oskarżony przyznał się do współpracy z wywiadem ościennego państwa, któremu sprzedawał uzyskane w czasie służby informacje ${ }^{19}$.

Poza środowiskiem wojskowych dziennikarz wskazał również kłopot w obrębie administracji publicznej, sprawowanej często w młodej Rzeczypospolitej przez przypadkowe osoby, które zaradnością życiową czy majątkiem pozyskały zaufanie społeczne i wykorzystując je, pracowały na rzecz wrogich instytucji czy państw. Szczególnie bulwersujące były przypadki

${ }^{16}$ Część szczególna, Rozdział XVII-XVIII, a także następująca po rozdziale osiemnastym zatytutowana "Szpiegostwo i niektóre inne przestępstwa przeciwko państwu", [w:] J. Makarewicz, Kodeks Karny z komentarzem, Lwów 1932, s. 179-215.

17 Nowy etap, s. 231.

18 Skazanie na śmierć dwu b. oficerów, którzy uprawiali szpiegostwo, „Gazeta Szamotulska: niezależne pismo narodowe, społeczne i polityczne" [dalej: GSz] nr 41, z 7 kwietnia 1927 r., s. 2.

${ }^{19}$ Mikuła agentem szajki szpiegowskiej, „Dziennik Poznański” [dalej: DzP], nr 17 z 22 stycznia 1927 r., s. 5. 
osób, które po odbyciu wyroku pozbawienia wolności za szpiegostwo wracały na wcześniej pełnione stanowiska. Przypomniano przypadek Zygmunta Kaczkowskiego, który cieszył się autorytetem, kiedy został oskarżony o szpiegostwo, opinia publiczna przekonana była o jego niewinności, tymczasem on okazał się winny ${ }^{20}$.

Z większym obiektywizmem traktowano przypadkowe osoby parające się współpracą z obcym wywiadem. Ich sprawy sądowe czy informacje o aresztowaniu były zazwyczaj krótkie i rzeczowe. Było tak zarówno w przypadku Franciszka Kubackiego, który współpracował z Abwehrą ${ }^{21}$, oraz rolnika z Sulmierzyc, któremu karę śmierci, dzięki prawu łaski przysługującemu Prezydentowi, zamieniono na dożywotnie więzienie ${ }^{22}$, jak i prywatnego detektywa Antoniego Halemby ${ }^{23}$.

Za trzyletnią współpracę z wywiadem niemieckim polscy obywatele skazani zostali na kary od roku do pięciu lat pozbawienia wolności. Stosunkowo niskie kary należy wiązać z marginalną rolą odgrywaną przez oskarżonych (trzech mężczyzn). Mieli oni dokonać uwolnienia więźniów politycznych, którzy zbiegli z więzienia, a także dokonać zniszczenia pomników powstańców śląskich, gazeta nie podała jednak, czy zatrzymano ich przed popełnieniem przestępstw, czy po wykonaniu zadań ${ }^{24}$. Łagodne wyroki nie wzbudzały aprobaty prasy. Kiedy zaś kara śmierci orzekana była za szpiegostwo, otwarcie pisano o tym, że była zasłużona, a żywot zdrajcy nazywano haniebnym. Wzbudzano również uczucia nienawiści wobec oskarżonych o szpiegostwo, pisząc o ich przebiegłości, majątku czy w przypadku kobiet urodzie, którą wykorzystywały prowadząc intrygi. Jedną z „bardzo urodziwych” była Stella Filarowa. Szczegółów jej sprawy dziennikarzom nie udało się ustalić, ponieważ sędziowie zdecydowali utajnić nie tylko przebieg rozprawy, lecz i dokładne brzmienie aktu oskarżenia ${ }^{25}$.

$\mathrm{W}$ rozprawach w sądzie poznańskim wielkie zainteresowanie wzbudziła sprawa sowieckiego szpiega Lipskiego. Prasa zbulwersowana była faktem długiej działalności szpiega, który po raz pierwszy na warszawskich salonach miał się pojawić w 1919 r. Sprawa Lipskiego została opisana w prasie w 1927 r., wówczas został schwytany w Poznaniu. Niekwestionowana wina stała się powodem wydalenia Lipskiego z Polski. Ten jednak po kilku latach pobytu we Francji wrócił do Polski i rozpoczął działania w Wielkopolsce. Aresztowanie Lipskiego w Poznaniu było jednym z działań związanych z wykryciem przez

\footnotetext{
${ }^{20}$ Szpiegostwo w Polsce, „Myśl Niepodległa” nr 568 z 3 września 1921 r., s. 564.

${ }^{21}$ Szpieg niemiecki schwytany na goracym uczynku, "Nowy Kurier” (Poznań) [dalej: NK], nr 137 z 15 czerwca 1930 r., s. 9.

22 Szpieg skazany na karę śmierci, NK nr 196 z 27 sierpnia 1932 r., s. 8.

${ }^{23}$ Dziśs sąd nad Tuchaczewskim i tow., NK nr 132 z 12 czerwca 1937 r., s. 1.

24 Surowy wyrok za szpiegostwo, NK nr 251 z 30 grudnia 1929 r., s. 2.

${ }^{25}$ W cieniu szubienic..., NK nr 258 z 9 listopada 1933 r., s. 3.
} 
poznańską Policję Polityczną komunistycznej siatki szpiegowskiej. To, co rozpoczęło się w stolicy wielkopolski od aresztowania Lipskiego, przybrało rozmiary ogólnopolskich działań, w efekcie których rozbito dużą siatkę szpiegowską, działającą na terenie Polski prawdopodobnie od okresu wojny ${ }^{26}$.

W 1931 r. niezwykły rozgłos towarzyszył sprawie szpiega sowieckiego Lipszyca (legitymował się dokumentami na nazwisko Bogdanow). Znany był jako polski obywatel, inżynier, który w środowisku poznańskich przemysłowców cieszył się dobrą opinią. W dużej mierze było to zasługą jego dobrego kolegi, wicestarosty poznańskiego Huberta. Początkowa dobra passa szpiega Lipszyca znalazła swój smutny finał cztery lata później, o czym obszernie donosił „Nowy Kurier”. Prasa ujawniała zawiłe meandry sprawy, zgodnie z którymi sowiecki szpieg miał być powiązany poprzez prowadzone interesy z ówczesnym wicestarostą poznańskim. Koniec intrygi, który nastąpił w Poznaniu, był tragiczny. Lipszyc został znaleziony martwy w okolicach Cytadeli. Policja podejrzewała „samobójstwo"27.

Losy jednego z najzdolniejszych polskich wywiadowców rtm. Jerzego Sosnowskiego wzbudzały żywe zainteresowanie opinii publicznej, do dziś postać rotmistrza bywa przedmiotem badań i sporów historyków. Wobec obszernej literatury traktującej o losach Sosnowskiego wypada jedynie zaznaczyć, że tzw. „, afera Sosnowskiego” omawiana była nie tylko w salonach i kawiarniach całego kraju, lecz i na łamach prasy. Zajmowano się jednak nie samą postacią przystojnego rotmistrza ani nawet jego osiągnięciami, lecz agentkami, które - jak podawały gazety - z miłości miały być gotowe do każdego poświęcenia. Tytuł artykułu w "Gazecie Szamotulskiej”: Przez miłość do szpiegostwa i na ... szafot! dodawał dramatyzmu całej historii, którą dziennikarze rozpoczęli od poinformowania o ścięciu toporem dwóch arystokratek niemieckich. O ile wobec zdrajców Polski nie wzbudzano współczucia ani litości, o tyle w przypadku Niemek pisano: „Przykład strasznego wyroku podziałał jak najbardziej odstraszająco i każdy dowiedział się do jakiej brutalnej nawet stanowczości zdolny jest ustrój, który państwo stawia nade wszystko, a życie jednostki uważa za nic" 28 .

Gazeta przedstawiła kochankę rotmistrza Benitę von Falkenhayn (van Berg - po drugim mężu) jako kobietę niezwykłej urody, żonę wynalazcy motoru do samolotów, którego dokładny szkic miał potem za jej pośrednictwem oglądać Sosnowski. Jej dwiema współpracowniczkami były panny pracują-

26 Szpieg Lipski, „Myśl Niepodległa”, nr 849 z 22 stycznia 1927 r., s. 53-54; Poznań dał poczatek wykryciu olbrzymiej afery szpiegowskiej, DzP, nr 15 z 20 stycznia 1927 r., s. 3.

27 Tajemnica sowieckiego szpiega Lipszyca-Bogdanowa przed sądem grodzkim w Poznaniu, NK, nr 211 z 13 września 1931 r., s. 1.

${ }^{28}$ Zob. m.in.: H. Ćwięk, Na tajnym froncie polsko-niemieckim: kulisy działalności rotmistrza Jerzego Sosnowskiego, Częstochowa 2005 (tam obszerna literatura); Przez mitość do szpiegostwa i na... szafot!, GSz, nr 26 z 28 lutego 1935 r., s. 2. 
ce na stałe w Reichswehrze (Renate von Natzmer, Irene von Jena). Do fiaska działań rotmistrza doprowadzić miała matka panny von Jena, która udała się na skargę do przełożonego córki. Przedmiotem wizyty były późne powroty córki do domu, a że dziewczyna tłumaczyła je licznymi obowiązkami zawodowymi, kobieta udała się do jej szefa ze skargą. Ten nakazał śledzić dziewczynę i tak sprawa została odkryta. Nie bez przesadzonego dramatyzmu gazeta podała, że pani van Berg tuż przed egzekucją wzywała ukochanego, który notabene został skazany na ciężkie więzienie. Podkreślano też dotkliwość kary, kobietom nie przysługiwało rozstrzelanie, zwyczajowo orzekane w przypadkach szpiegostwa, skazano je na haniebną śmierć przez ścięcie toporem ${ }^{29}$. Ujawnienie działań Sosnowskiego w Niemczech wywołało sensację, surowe wyroki dla kobiet były potwierdzeniem przesłanek dotyczących rządów młodego wówczas przywódcy Niemiec Adolfa Hitlera, który - jak ujawniała prasa - osobiście wpłynął na dotkliwość kar. Sprawa mjr. Sosnowskiego nie była jedyną, która poruszyła opinię publiczną, choć jej przebieg był dramatyczny, to ostatecznie życie rotmistrza zostało ocalone. Inaczej zupełnie niż w przypadku funkcjonariusza Korpusu Ochrony Pogranicza, który swoją pomyłkę przypłacił życiem.

Rzecz miała miejsce na granicy Rzeczypospolitej i Związku Sowieckiego. Por. Janik konno patrolował granicę polsko-sowiecką, przeoczył jeden ze słupków granicznych i znalazł się po stronie sowieckiej, tam został pochwycony przez Armię Czerwoną i oskarżony o szpiegostwo. Postanowiono go zawieźć do Mińska. Podczas transportu (drezyną) doszło do wypadku, w którym Janikowi i żołnierzom go eskortującym nic się nie stało, ale członek Wszechrosyjskiej Komisji Nadzwyczajnej do Walki z Kontrrewolucją i Sabotażem (Czeka, potocznie z ros. Czerezwyczajka) Ochmański poniósł śmierć. Wypadek i jego skutki przypisano działaniom Janika, któremu obok zarzutu szpiegostwa postawiono jeszcze oskarżenie o działalność terrorystyczną i zamach na Ochmańskiego. Strona polska niezwłocznie po otrzymaniu informacji o zatrzymaniu funkcjonariusza interweniowała, próbując zapobiec nieszczęściu. Niestety, Sowieci pozostali niewzruszeni, nie okazali względów ani dla stosunków dyplomatycznych, ani poczucia sprawiedliwości. Porucznika skazano na śmierć przez rozstrzelanie, wyrok wykonano w kilka godzin po ogłoszeniu ${ }^{30}$.

Sytuacja państwa polskiego po odzyskaniu niepodległości spowodowała, jak donosił dziennikarz „Myśli Niepodległej”, że obywatele przyzwyczaili się do obecności szpiegów, a ich sprawy były rozpatrywane zbyt, jego zdaniem, pobłażliwie: „[...] zaczęto u nas patrzeć na szpiegostwo niemal jak na coś normalnego [...]. Szpiegów oraz cudzoziemskich dywersantów nie tylko

\footnotetext{
29 Tamże.

30 Sowiety rozstrzelaty niewinnego oficera polskiego, NK nr 137 z 18 czerwca 1927 r., s. 1.
} 
ułaskawiono, nie tylko traktowano jako towar dyplomatycznych pertraktacji, lecz w dodatku zaczęto uważać niemal za »ludzi idei«, którzy mają prawo do jakichś wyjątkowych względów"31.

Wiele miejsca poświęcano żołnierzom na co dzień przebywającym w środowisku międzynarodowym, a także wszystkim młodym wojskowym, których pochodzenia - jak donosiła prasa - nikt nie sprawdzał ${ }^{32}$. Jako szczególnie niebezpieczne wskazywano powierzanie obcokrajowcom wysokich funkcji w wojsku bądź ministerstwach. Sugerowano nawet, że Niemcy, dzięki takiemu postępowaniu Polaków, wiedzieli o naszym wojsku więcej niż sami Polacy ${ }^{33}$. Nie oszczędzono szczególnie tych żołnierzy, którzy ożenili się z cudzoziemkami, traktując te panie jako wymagające szczególnej obserwacji, a nawet weryfikacji. Redaktor był jednak poruszony przypadkiem pewnej Rosjanki przyłapanej na szpiegostwie przez żołnierzy żandarmerii, którzy mieli ulec jej urokowi osobistemu, darować winę i doprowadzić następnie do zatuszowania sprawy, aranżując ożenek z polskim oficerem, który stanowił gwaranta lojalności żony wobec nowej ojczyzny. Redakcja gazety sugerowała, że takie rozwiązania nie tylko niczego nie utrudniały, lecz nawet ułatwiały pracę kobiecie ${ }^{34}$.

Nie brakowało $\mathrm{w}$ prasie przykładów kobiet zaangażowanych $\mathrm{w}$ afery szpiegowskie, piętnowano szczególnie te wykorzystujące urodę i koneksje dla osiągania celów, zimne, wyrachowanie zdrajczynie, które nie miały w sobie żadnych uczuć patriotycznych, gotowe służyć temu, kto da więcej. Tymczasem $\mathrm{w}$ jednej z głośnych spraw szpiegowskich dwudziestolecia międzywojennego chlubnie zapisała się pewna Polka. Z gdańskiego Prezydium Policji prowadzono akcję szpiegowską Niemiec ukierunkowaną na Polskę. Jednym z urzędników Prezydium Policji był niejaki Walter Oslow, który nawiązał kontakt z panną Czesławą W., przebywającą w Gdańsku. Mężczyzna, dowiedziawszy się, że posiadała ona koneksje w kręgach wojskowych, postanowił uczynić z niej szpiega niemieckiego. Z obszernego artykułu czytelnicy dowiedzieli się o sprytnej grze, którą podjęła kobieta. Nie odmawiając i nie zgadzając się zarazem, dowiedziała się, jakie ma być jej zadanie. Chodziło

${ }^{31}$ Nowy etap walki ze szpiegostwem, s. 229.

32 Zarzuty niefrasobliwego podejścia polskich organów wojskowych wobec obcokrajowców w polskim wojsku nie były słuszne, czego dowodem chociażby sprawa ppor. Stanisława Appenzellera, urodzonego we Francji, w przypadku którego brak polskiego obywatelstwa był jednym z powodów wymienianych jako przeszkoda $w$ drodze do awansu, zob. Centralne Archiwum Wojskowe [dalej: CAW], Akta personalne Stanisława Bernarda Appenzellera, sygn. I481.A.2039. Pismo Ministerstwa Spraw Wojskowych, Departamentu Żeglugi Powietrznej (IV) w sprawie mianowania na ppor. rez. Stanisława Appenzellera z 20 III 1923 r.. Zob. P. Kanafocka, Wywiad w cieniu polityki. Stanisław Bernard Appenzeller - szara eminencja polskich stużb specjalnych (1939-1945), [w:] Na obrzeżach polityki, cz. 10, pod red. M. Kosmana, Poznań 2014, s. 44.

33 Szpiegostwo w Polsce, s. 563.

${ }^{34}$ Tamże. 
o zamordowanie lub spowodowanie ciężkiego uszczerbku na zdrowiu polskiego oficera, przedstawiciela Poselstwa Polskiego w Gdańsku. Kobieta zgodnie z wytycznymi prowadzącego ją miała udać się do Polski. Zaraz po przyjeździe do kraju zgłosiła sprawę władzom ${ }^{35}$.

Wnikliwy czytelnik mógł dostrzec $\mathrm{w}$ idealizowanej przez gazetę postaci panny Czesławy rysę. Warto zaznaczyć, że kobieta - zgodnie z informacjami z artykułu - otrzymywała kilka mniej znaczących zadań, za wykonanie których obiecano jej wynagrodzenie. Mimo że podpisała stosowne dokumenty, otrzymała tylko część pieniędzy, na pozostałe miała poczekać aż zostaną przesłane z Berlina, tymczasem dano jej kolejne zadanie. Możemy się jedynie domyślać, czy skierowanie się do polskich władz było rezultatem wyrzutów sumienia, świadomej gry, czy raczej rozgoryczenia niesłownością zleceniodawców?

Sprawa gdańskiego Prezydium Policji i jego antypolskiej działalności wracała na łamy prasy wielkopolskiej kilkakrotnie. Kolejnym bohaterem szpiegowskiej gry był Wincenty Tomczik z Tarnowskich Gór, który trafił do Prezydium Policji za sprawą mjr. Wagnera (kierownika Heimatdienstu). Tomczik znany był polskiej Policji Politycznej z działań prowadzonych w Poznaniu. W Gdańsku funkcjonował pod nazwiskiem Leo Halling, jego głównym zadaniem było preparowanie zarzutów wobec lojalnych Polsce urzędników. Sfingowane dokumenty świadczące o ich współpracy z wywiadem niemieckim „przypadkiem” podrzucał w miejscach ich pracy, czym kompromitował osoby w oczach pracodawców i zwracał na nie uwagę lokalnych służb bezpieczeństwa ${ }^{36}$.

Wiele spraw związanych ze zdradą kraju toczących się na jego terytorium rozpatrywała prasa. Jedne bardziej szczegółowo, inne mniej, stopień wnikliwości dziennikarzy uzależniony był nie tylko od tego, na ile sumiennie przykładali się do swojego dziennikarskiego rzemiosła, lecz i od ogólnej wiedzy opinii publicznej, która z kolei polegała na pochodzących z sądów i samego kontrwywiadu wieści. Gdy sprawy sądowe odbywały się przy drzwiach zamkniętych, atmosferę budowano, doszukując się powodów takich postanowień i spekulując o wyrokach, a także niebezpieczeństwie, gdy zaś przy otwartych, to poszukiwano wiadomości sensacyjnych dla czytelników, niezależnie od tego, czy miały związek bezpośredni z toczącym się procesem czy nie. Piętnowano zdrajców, ale równie nieustępliwie dociekano spraw doty-

35 Prezydium policji w Gdańsku gniazdem szpiegostwa przeciw Polsce, NK, nr 211 z 13 września 1931 r., s. 4.

${ }^{36}$ Dalsze dowody winy Polizeipräsidium w Gdańsku, DzP, nr 211 z 13 września 1931 r., s. 3; Co pisza inni, DzP, nr 203 z 4 września 1931 r., s. 3 - zwerbowanie przez szpiega Sowę dezertera z wojska polskiego; Na ustugach wywiadu niemieckiego znajduje się Polizeipräsidium w Gdańsku, DzP, nr 208 z 10 września 1931 r., s. 1; Gdańsk prowadzi akcje szpiegowska przeciw Polsce, DzP, nr 209 z 11 września 1931 r., s. 1. 
czących Rzeczypospolitej, jeśli była ona przedmiotem działań prowadzonych przez służby państw ościennych. Nie zaskakuje, że pod nieco enigmatycznym określeniem „państw ościennych” kryją się właściwie dwa państwa Rosja Sowiecka i Niemcy (zarówno Republika Weimarska, jak III Rzesza Niemiecka prowadziły intensywne operacje wywiadowcze za swoją wschodnią granicą).

Wiele emocji wzbudzała antypolska polityka Niemiec. Prasa śledziła decyzje rządu i parlamentu niemieckiego, piętnując niekorzystne dla Polaków decyzje. Głośno debatowano nad przeznaczeniem ośmiu milionów marek na tajny fundusz propagandowy, sugerując jednocześnie, że zasadnicza część tej kwoty miała zostać przeznaczona na działalność w Polsce. Poza tą kwotą wyasygnowano dodatkowy milion na działania wywiadu w Polsce i innych państwach. Jeden z niemieckich dzienników, na który powoływała się redakcja „Dziennika Poznańskiego", podawał, że poza sumami znanymi opinii publicznej były jeszcze dodatkowe środki na realizację wspólnych niemieckosowieckich celów ${ }^{37}$.

W 1931 r. polskie społeczeństwo żyło wydarzeniami w Małopolsce Wschodniej. Zamordowany został poseł polski Tadeusz Hołówko, który znany był jako osoba mająca na celu przywrócenie przyjaznych relacji polskoukraińskich. Jego śmierć i trudności, które napotykali śledczy, zaprowadziły prasę małopolską do Berlina. Tam bowiem miały się znajdować pośród urzędników (Ministerstwa Spraw Zagranicznych i Reichswery) osoby pomagające w ustaleniu alibi dla morderców. Był to jeden z elementów współpracy niemiecko-ukraińskiej wymierzonej w Polaków ${ }^{38}$. Trudna politycznie sprawa z uwagi na coraz bardziej napięte relacje polsko-niemieckie stała się głównym tematem nie tylko salonów kawiarnianych, lecz i politycznych. Wobec opublikowania dokumentów świadczących na niekorzyść Niemców (dwa listy niemieckiego ministra spraw zagranicznych $\mathrm{w}$ związku z finansowaniem ukraińskich akcji sabotażowych w Małopolsce Wschodniej), sprawy tej nie mógł bagatelizować także Berlin ${ }^{39}$. Niemcy, wykorzystując specjalne fundusze propagandowe, prowadzili pośród Ukraińców antypolską działalność, głosząc rzekomą nieprzychylność Polaków wobec Ukrainy i jej spraw. Prasa podawała, że akcje sabotażystów i terrorystów były wymierzone przeciwko Polsce, a gazety krakowskie miały na to nawet dowody w postaci korespondencji polityków, a także dokumentów ${ }^{40}$. Z nich właśnie wynikało, że konsulowie niemieccy w Polsce odbywali podróże po kraju i spotkania, których

\footnotetext{
37 Tajne gadzinowe fundusze na szpiegostwo w Polsce, DzP, nr 33 z 11 lutego 1927 r., s. 2.

${ }^{38}$ Niech mówia dokumenty, "Ilustrowany Kurier Codzienny” (Kraków) [dalej: IKC], nr 251 z 11 września 1931 r., s. 1; I. Werschler, Z dziejów obozu belwederskiego. Tadeusz Hołówko, życie i działalność, Warszawa 1984, s. 310-342.

39 Tamże, s. 1-3.

${ }^{40}$ Dalsze dowody winy Polizeipräsidium w Gdańsku.
} 
efektem było pozyskanie osób i środków finansowych na prowadzenie akcji sabotażowych ${ }^{41}$.

Obok kłopotów na kierunku zachodnim zmagano się również z problemami w relacjach ze Wschodem. Szczególnym zmartwieniem była intensywna działalność Zarządu Wywiadowczego Sztabu Robotniczo-Chłopskiej Armii Czerwonej (zwanego z rosyjska w skrócie Razwieduprem), prowadzona - jak podano - w krajach sąsiednich. Wywiad sowiecki działał pośród mniejszości rosyjskiej, ukraińskiej, a także w kręgach politycznych dla pozyskania zwolenników komunistycznych i przeciwdziałania antykomunistycznym posunięciom rządu polskiego ${ }^{42}$.

Poza informacjami o działalności szpiegowskiej na terytorium Polski nie stroniono od zagadnień związanych z działaniem wywiadów różnych państw $\mathrm{w}$ środowisku międzynarodowym. Prasa zajmowała się sytuacją w państwach sąsiadujących z Polską, ze szczególnym uwzględnieniem Niemiec i Rosji Sowieckiej. Gazety poznańskie zajmowały także sprawy Francji, Stanów Zjednoczonych, oraz działania wywiadu japońskiego.

Najwięcej miejsca poświęcono działaniom wywiadu niemieckiego i rosyjskiego, nie stroniono nawet od zamieszczania przykładów działania jeszcze z czasów wojny 1914-1918. Bohaterem Rosjan był wówczas kpt. Andrzej Pekka, który pracował na kierunku niemieckim. Centrala wywiadu rosyjskiego na Austrię i Niemcy podczas wojny mieściła się w Warszawie (przynajmniej do czasu zajęcia Warszawy przez Niemców), jej kierownikiem był płk Batiuszyn. Praca pułkownika wzbudzała aprobatę przełożonych, ponieważ przez cały okres działania został zaledwie dwukrotnie odkryty, co i tak nie wpłynęło na rezultat pracy. Pozyskane w wyniku operacji materiały były zabezpieczone $\mathrm{w}$ momencie, gdy kontrwywiad niemiecki zorientował się w działaniu dwóch swoich wiarołomnych oficerów (jeden z Twierdzy Toruń, drugi Wrocław). Najbardziej spektakularnym działaniem było pozyskanie jako źródła, szefa cesarsko-królewskiego sztabu wojsk austriackich płk. Redla, który dostarczał wszelkich informacji o działaniach Austriaków, a współpracę zakończyła dopiero samobójcza śmierć wspomnianego szefa sztabu $^{43}$. Pułkownik, choć zdolny i świetnie zorganizowany, nie mógł wszystkich zadań wykonywać sam, stąd też podlegali mu funkcjonariusze wyspecjalizowani $\mathrm{w}$ różnych formach działania. Jednym z nich był szef odcinka Ryga-Mińsk, który siedzibę swojej placówki miał w Rzeczycy, w budynku szkolnym. Stamtąd prowadził rekrutację chętnych do działań szpiegowskich

41 Wstrzasające wrażenie relacji IKC o zdradzieckiej robocie Berlina, IKC, nr 252 z 12 września 1931 r., s. 10.

42 Szpiegowskie nici rządu sowieckiego, „Gazeta Międzychodzka. Pismo poświęcone obronie Kresów Zachodnich", nr 127 z 30 października 1925 r., s. 2.

${ }^{43} \mathrm{Kpt}$. Pekka - as wywiadu rosyjskiego, "Orędownik. Ilustrowane pismo narodowe i katolickie” (Poznań) [dalej „Orędownik”], nr 270 z 19 listopada 1936 r., s. 3. 
i tam obmyślał fortele. Przez cały okres wojny ani razu go nie schwytano. Potrafił trafnie dobierać współpracowników, osobiście kontrolował przebieg szkolenia. Spośród młodych adeptów szpiegostwa połowa trafiała na stronę niemiecką, skąd okrężną drogą przesyłała interesujące wywiad rosyjski informacje. Gazeta podkreślała spryt pułkownika, który polecił szpiegom używać psów do przekazywania informacji, niestety, zachowanie zwierząt nie zawsze było przewidywalne, czego efektem była dekonspiracja działań kilkunastu szpiegów zakończona ich śmiercią ${ }^{44}$. Nawet tak rażąca klęska nie wpłynęła ujemnie na ocenę działań Pekki. Po wojnie skończył studia medyczne i fizykomatematyczne, zamieszkał w Rydze ${ }^{45}$.

Zainteresowanie wzbudzały również działania wywiadu niemieckiego, nawet te prowadzone daleko od Rzeczypospolitej. Redakcja "Orędownika” zamieściła informację z Nowego Jorku dotyczącą oskarżenia czwórki obywateli niemieckich m.in. o sfałszowanie podpisu prezydenta Franklina Delano Roosevelta. Zgoda prezydenta była potrzebna do uzyskania dostępu do tajnych informacji o lotniskowcach amerykańskich. Pozyskiwane w Stanach Zjednoczonych informacje przesyłane były do Rzeszy za pośrednictwem Niemców, którzy mieszkali w Stanach Zjednoczonych. Jeden z niemieckich szpiegów chwalił się, że posiada źródła w każdym dużym zakładzie przemysłu lotniczego. Cała grupa, trzech mężczyzn i kobieta, została schwytana, gdy udając turystów, fotografowali w miejscowości Colon nad Kanałem Panamskim fortyfikacje kanału ${ }^{46}$.

Pośród niemieckich szpiegów oraz informatorów znajdowały się także kobiety. Jedną z bardziej znanych była nieuchwytna niemiecka agentka Maria Luiza operująca m.in. we Francji i Holandii. Jej ostatnią misją było zwerbowanie młodego oficera szkockiego przebywającego w Holandii. Mężczyzna w czasie sprawy sądowej utrzymywał, że nie wiedział, iż podająca się za studentkę kobieta była niemieckim szpiegiem. Ona sama była obserwowana przez wywiady francuski i angielski, jednak żaden z nich nie miał wystarczających dowodów, aby ją zatrzymać. Szkot w toku całej sprawy sądowej wierzył, że Maria Luiza, którą uważał za damę, zaświadczy o jego niewinności. Kobieta jednak nie pojawiła się w sądzie. W końcu świat obiegła informacja o jej śmierci, zmarła w wyniku zapalenia płuc ${ }^{47}$.

Czasem nawet szpiedzy uważani za niezwykle niebezpiecznych popełniali błędy, które wzbudzały wątpliwości co do ich legendarnych umiejętności. Przebywająca w Londynie córka jednego z maharadżów hinduskich,

44 Tamże.

45 Tamże.

46 Szpiedzy niemieccy w Stanach Zjednoczonych, „Orędownik”, nr 241 z 19 października 1938 r., s. 1.

${ }^{47}$ Maria-Luiza, tajemnicza agentka wywiadu niemieckiego, „,Orędownik Wielkopolski. Ludowy dziennik narodowy i katolicki" (Poznań), nr 156 z 11 lipca 1933 r., s. 3. 
studentka London School of Economics, obracała się w środowisku oficerów RAF i pozyskiwała dla obcego mocarstwa (prasa nie podała którego) istotne informacje wojskowe. Jej działania wyszły na jaw, kiedy wracając wieczorem z klubu, zostawiła w taksówce torebkę, którą kierowca zaniósł do prezydium policji. Tam odnaleziono, obok informacji o miejscu zamieszkania kobiety, list do znanego Secret Service muzyka. Z listu jednoznacznie wynikało, że kobieta szpiegowała na rzecz obcego wywiadu. Mimo tych informacji, nie udało się jej schwytać, zdążyła opuścić Anglię ${ }^{48}$.

Żaden z wywiadów państw europejskich nie wzbudzał sensacji, metody, którymi się kierowały, były podobne, podobna struktura, skuteczność zaś uzależniona zarówno od środków finansowych, jak i zasobów ludzkich. Za niedościgniony wzór uważano wywiad japoński. Podziw wcale nie był związany ze skutecznością działań, ale stosowanymi metodami. Japończycy działali z subtelnością i wyczuciem, uśmiechem i otwartością zdobywali przychylność oraz zaufanie, ich zainteresowanie wszelkimi sprawami Zachodu przejawiało się $\mathrm{w}$ formie podziwu i nadzwyczajnych pochwał, które kierowano pod adresem przemysłowców, polityków czy wojskowych. Nie było $\mathrm{z}$ ich strony pytań o tajemnice ani określone dokumenty, a mimo to dowiadywali się wszystkiego, czego potrzebowali. Europejczycy ukontentowani pochwałami sami chętnie opowiadali o nowinkach w przemyśle czy technologii, z otwartością traktowali młodych, uśmiechniętych i pracowitych stażystów z Japonii. Przyjmowano ich na wyższe uczelnie, do zakładów przemysłowych, okazywano zaufanie, oni zaś "tylko" obserwowali. Szpiegostwo przemysłowe Japonii przybierało najwyższe formy, wysłannicy Kraju Kwitnącej Wiśni znajdowali się na wszystkich kontynentach, pozyskując i dostarczając zwierzchnikom $\mathrm{w}$ wywiadzie informacji ${ }^{49}$. Podkreślano ich odwagę, a nawet brawurę, zwracano również uwagę na umiejętność rozpoznania psychologii przeciwnika, dostosowania się do jego nastrojów, sposobu myślenia czy procesów decyzyjnych w strukturach wojskowych bądź przemysłowych. Podczas rewolucji rosyjskiej (1918-1921), do szofera jednego z dowódców Armii Czerwonej zgłosił się por. Kyoki, który nakazał dostarczyć transport karabinów maszynowych z magazynów Armii Czerwonej. Broń miała być przeznaczona dla walczących Chińczyków ${ }^{50}$. Poruszenie międzynarodowe wzbudziła również informacja o aferze szpiegowskiej w Stanach Zjednoczonych, gdzie w wyniku zdrady Amerykanina podającego się za marynarza Japonia weszła $w$ posiadanie odpisów tajnych dokumentów amerykańskiej marynarki wojennej. Sowicie wynagradzany przez oficera prowa-

48 Córka maharadży niebezpiecznym szpiegiem, "Gazeta Powszechna” (Poznań), nr 175 z 2 sierpnia 1939 r., s. 3.

49 Z działalności japońskiego tajnego wywiadu, GSz, nr 42 z 6 kwietnia 1935 r., s. 1.

50 Tamże. 
dzącego Amerykanin został odkryty i postawiony przed sądem. Okazało się wówczas, że na kilku innych okrętach japoński wywiad dzięki Thompsonowi również miał oddanych współpracowników ${ }^{51}$.

Dla zachodniokresowych Polaków istotne były wszystkie informacje napływające z mediów, a dotyczące walki ze szpiegostwem. Ogromna praca poznańskiego kontrwywiadu wojskowego, a także Policji Politycznej widoczna była dla mieszkańców dopiero wtedy, kiedy media mogły o niej napisać. Warto podkreślić, że zamieszczanie artykułów dotyczących szpiegów i szpiegostwa odgrywało niepoślednią rolę. Pomijając wspomniane już uświadomienie mieszkańcom, kto stoi na straży bezpieczeństwa, przybliżenie pracy służb specjalnych obywatelom korzystnie wpłynęło na ich wizerunek. Było to o tyle istotne, że zarówno Policja, jak służby wywiadu i kontrwywiadu wojskowego państw zaborczych kojarzyły się z systemem represyjnym, inwigilacją, a we wschodniej części Polski również z korupcją. Pokazanie prawdziwej działalności budowało wizerunek służb, podnosiło zaufanie wobec funkcjonariuszy.

Nawet jeśli wziąć pod uwagę, że niejednokrotnie w gazetach zamieszczane były informacje z sal sądowych oraz krótkie komunikaty starannie opracowane i sprawdzone (?) przez służby specjalne, to pojawianie się ich powodowało wzrost poczucia bezpieczeństwa, ale też kształtowało w obywatelach potrzebę ciągłej ostrożności i odpowiedzialności za losy ojczyzny. O zagrożeniu szpiegostwem na świecie przekonywały również raporty publikowane w prasie. W artykule zatytułowanym Pót miliona szpiegów w Europie podano za gazetami amerykańskimi informacje o szacunkowej liczbie szpiegów. Następnie wymieniono z podziałem na miesiące najbardziej spektakularne afery szpiegowskie zakończone aresztowaniami. Jednocześnie podano, że zaledwie trzystu szpiegów zostało schwytanych w Europie w ciągu 1933 r. Dane nie obejmowały Polski, tak więc nie były miarodajne, ponadto, jak wskazywano, prasa amerykańska skoncentrowała się na szpiegach wojennych, traktując sprawy wybiórczo. Podane liczby nie były dokładne również z uwagi na to, że część rozpraw sądowych odbywała się za zamkniętymi drzwiami, bez udziału, a czasem i wiedzy mediów ${ }^{52}$.

Podejmowanie tematu szpiegostwa w mediach pełniło funkcję dydaktyczną. Nie tylko umoralniającą, pokazującą, że za zdradę zawsze spotyka kara, ale też wskazującą na określonych przykładach, kim może być szpieg bądź też za kogo się zazwyczaj podaje, jakich informacji poszukuje, jakie są stosowane przez niego metody. Czytując regularnie prasę, można było otrzymać pewien ogólny rys postaci szpiega i jego działania. Szpiegostwem parali się zarówno żołnierze, jak dyplomaci, ale też: arystokracja, artyści, tacy jak for-

51 Wielka afera szpiegowska w Stanach Zjednoczonych, NK, nr 148 z 27 czerwca 1936 r., s. 1.

52 Pót miliona szpiegów w Europie, NK, nr 177, z 5 sierpnia 1934 r., s. 6. 
danserka Majewska ${ }^{53}$, córka hinduskiego maharadży, prywatny detektyw czy też fryzjerka ${ }^{54}$, córka bankiera ${ }^{55}$, było to niezwykle barwne środowisko stanowiące interesujący przekrój charakterów i osobowości. Rozpoczynając operację, szpieg musiał mieć stworzoną legendę, na tyle wiarygodną, aby wprowadzić w błąd wszystkich, począwszy od osób, z którymi spotykał się, realizując zadanie, aż do urzędników czy podejrzliwych służb bezpieczeństwa. Za kogo podawali się szpiedzy, których sylwetki przywoływano w mediach?

W zależności od tego, w jakim gronie osób mieli realizować zadanie, podawali się albo za wpływowych kupców, przedsiębiorców, żołnierzy sojuszniczych armii, albo zwyczajnych pracowników, nauczycieli etc. W artykule o kpt. Andrzeju Pekka autorzy podkreślili, jak istotne było odpowiednie wybranie osób, które potem miały zajmować się szpiegowskim rzemiosłem. Tytułowy bohater na błędach oficera niemieckiego odpowiedzialnego za pracę wywiadowczą na jego odcinku (ale w przeciwnym kierunku) przekonał się, że nie każdy może być szpiegiem. Niemiec przewerbował wziętych do niewoli rosyjskich żołnierzy pochodzenia łotewskiego. Po przeszkoleniu zostali przerzuceni na tyły armii rosyjskiej w celu prowadzenia działań dywersyjnych. Tymczasem żołnierze udali się do oficerów rosyjskich i wyjaśnili im szczegóły zadań, których realizacji wymagał niemiecki wywiad ${ }^{56}$. Podobnie boleśnie przekonał się o wartości swojego szpiega wywiad, który wybrał do realizacji własnych zadań hinduską księżniczkę, ta zaś niefrasobliwie pozostawiła torebkę $\mathrm{w}$ taksówce. Ona, realizując zadanie, podawała się za studentkę, podobnie jak Maria Luiza pracująca dla Niemców ${ }^{57}$.

Pośród sylwetek wybieranych przez szpiegów były i bardziej nietypowe. Pracująca dla Niemców w Stanach Zjednoczonych kobieta podawała się za fryzjerkę pływającą na statku „Europa”, bez wątpienia ułatwiało to zarówno pozyskiwanie, jak przekazywanie informacji. Działający razem z kobietą mężczyzna podawał się za stroiciela fortepianów, co z kolei umożliwiało mu wchodzenie do domów wielu osób w sposób niewzbudzający podejrzeń $^{58}$. To niezwykłe zestawienie zamyka kapitan japońskiej armii, który po zakończeniu wojny w 1918 r. kontynuował działalność wywiadowczą, prowadząc duży i dobrze prosperujący dom publiczny. Gościł znakomite towarzystwo, które pod wpływem pobytu tam gotowe było rozmawiać o wielu sprawach, bez dodatkowej inspiracji ${ }^{59}$. Działający dla niemieckiego wywiadu

${ }^{53}$ W cieniu szubienic, s. 3.

54 Szpiedzy niemieccy w Stanach Zjednoczonych, s. 1.

55 Tamże.

${ }^{56}$ Kpt. Pekka - as wywiadu rosyjskiego, s. 3.

${ }^{57}$ Maria - Luiza, tajemnicza agentka wywiadu niemieckiego, s. 3; Córka maharadży niebezpiecznym szpiegiem, s. 3 .

58 Szpiedzy niemieccy w Stanach Zjednoczonych., s. 1.

${ }^{59} \mathrm{Z}$ działalności japońskiego tajnego wywiadu, s. 1. 
funkcjonariusze gdańskiego prezydium policji również zmieniali tożsamość. Charakteryzowała ich nie tylko dociekliwość, ale i przebiegłość. Wspomniany już Walter Oslow podczas rozpracowywania polskiego oficera należącego do Wydziału Wojskowego Komisariatu Generalnego RP w Gdańsku wszedł do wynajmowanego przez oficera mieszkania jako zdun, wprowadzony za zgodą właściciela kamienicy w celu przeglądu pieca. Sprawdzenia dokonywał w obecności służącej, z którą od razu rozpoczął rozmowę, obiecał nawet, że pozna ją z odpowiednim kawalerem (potem okazało się, że także funkcjonariuszem prezydium policji w Gdańsku). Operacja nie powiodła się, ponieważ służąca powiedziała pracodawcy o nietypowych pytaniach „,zduna”, pouczona przez oficera - nie wpuściła więcej „zduna” ani jego kolegi ${ }^{60}$.

Tworzenie legendy nie zawsze oznaczało wymyślenie całkowicie fikcyjnej, nieistniejącej wcześniej postaci, czasem wybierano zmarłe osoby albo podszywano się pod tych, którzy wyjechali wiele lat wcześniej. Pierwsza metoda z pewnością była bezpieczniejsza od drugiej. Działania szpiega Lipszyca-Bogdanowa wzbudzały wiele kontrowersji. Przy odnalezionych w pobliżu Cytadeli zwłokach były dokumenty wystawione na obywatela polskiego inż. Grigorija Bogdanowa, dopiero policja rozpoznała w nim szpiega znanego także europejskim służbom specjalnym, którego nazwisko brzmiało Lipszyc. Był to szpieg sowiecki, który podszywał się pod polskiego inżyniera, przedsiębiorcę działającego w Małopolsce Wschodniej krótko po zakończeniu wojny światowej. Dziennikarzom nie udało się ustalić, w jaki sposób wszedł w posiadanie dokumentów Bogdanowa ani dlaczego nie rozpoznał w nim oszusta wicestarosta poznański Hubert, który pracował z prawdziwym Bogdanowem ${ }^{61}$.

Drugi ze wspomnianych przypadek dotyczył Francuza, który po zajęciu ziem przez Niemców (w wyniku wojny prusko-francuskiej 1870-1871 Alzacja i Lotaryngia znalazły się pod panowaniem niemieckim) wyemigrował do Stanów Zjednoczonych. W Kalifornii Karol Hartmann uzyskał ogromną fortunę, dowiedziawszy o pomyślnym dla Francji wyniku wojny (1914-1918), a nade wszystko o odzyskaniu jego rodzinnych ziem przez Francje, jako 75letni mężczyzna wybrał się do ojczyzny. Tam dowiedział się, że podczas wojny został skazany za szpiegostwo na karę śmierci. Mężczyzna z łatwością udowodnił niewinność i został oczyszczony z zarzutów. Nie udało się odnaleźć rzeczywistego winowajcy ${ }^{62}$.

Wspólnym mianownikiem działań podejmowanych przez służby specjalne było i jest zdobywanie informacji o tym, co wpływało na szeroko pojmo-

\footnotetext{
60 Prezydium policji w Gdańsku s. 4.

${ }^{61}$ Tamże.

62 Szpiegowskie pokłosie Niemiec, „Gazeta Wągrowiecka: pismo dla Ziemi Pałuckiej”, nr 169 z 6 września 1930 r., s. 3.
} 
wane bezpieczeństwo państwa, na jego podtrzymanie albo kreowanie. Nie gromadzono przypadkowych informacji, oficer prowadzący lub agent, który budował siatkę szpiegowską, miał ścisłe wytyczne z centrali wywiadu, dotyczące „zapotrzebowania” na określone informacje. Nie bez znaczenia była sytuacja międzynarodowa, tzn. innych wiadomości poszukiwano w czasie pokoju, innych, przygotowując się do konfliktu zbrojnego, odmiennych jeszcze podczas toczących się na froncie walk. W czasie pokoju równie istotne było prowadzenie wywiadu wojskowego, co przemysłowego czy politycznego. Zamieszczane w gazetach artykuły nie były w całości poświęcane temu, jakich informacji poszukiwano, ale kiedy zatrzymywano szpiega, często podawano, czym się zajmował albo jakie dokumenty przy nim znaleziono. Na tej podstawie czytelnik mógł określić, czym interesowały się służby. Do najbardziej pożądanych należały: informacje dotyczące obrony ${ }^{63}$, plany mobilizacyjne, plany twierdz, plany konstrukcyjne nowych samolotó $w^{64}$. Znajdowano przy zatrzymanych szpiegach najczęściej: raporty i materiały wojskowe, fotografie fortów, umocnień obronnych ${ }^{65}$. Ogromne znaczenie miała wiedza o osobach odgrywających znaczącą rolę w wojsku bądź polityce. W sprawie gdańskiego prezydium policji pokazana bardzo wyraźnie ${ }^{66}$.

W sprawach nowych technologii i produkcji przemysłowej oraz wojskowej mistrzami byli Japończycy ${ }^{67}$. Niemcy celowali w tajemnice wojskowe, ze Stanów Zjednoczonych: o artylerii amerykańskiej w obrębie Kanału Panamskiego, o jednostkach marynarki Stanów Zjednoczonych na Atlantyku, o szczegółach dotyczących dwóch nowoczesnych lotniskowców amerykańskich $^{68}$, z Wielkiej Brytanii o obronie przeciwlotniczej, z Polski czerpali informacje na temat rozmieszczenia oddziałów wojsk na Pomorzu, poza tym nierzadko zlecali zadania dywersyjne, jak wspomniane wysadzenie pomników powstańców śląskich albo przeniknięcie do struktur wojskowych czy politycznych ${ }^{69}$.

Podczas wojny obok zbierania informacji istotną rolę odgrywało prowadzenie działań osłabiających wroga. Nauka przeprowadzania zadań dywersyjnych odbywała się w szkołach, których lokalizacja odpowiadała wyjątkowym działaniom wywiadowczym. Naturalnie, nie można było otwarcie pisać

${ }^{63}$ Zarówno obrony przeciwlotniczej, np. Londynu - zob. Córka maharadży niebezpiecznym szpiegiem s. 3; jak i obrony Pomorza - zob. Skazanie na śmierć dwu b. oficerów, którzy uprawiali szpiegostwo, s. 2.

${ }^{64}$ Pót miliona szpiegów w Europie s. 6.

65 Sowiety rozstrzelaty niewinnego oficera polskiego s. 1.

${ }^{66}$ Prezydium policji w Gdańsku, s. 4.

67 Z działalności japońskiego tajnego wywiadu s. 1.

68 Szpiedzy niemieccy w Stanach Zjednoczonych, s. 1.

${ }^{69}$ Zob. artykuły prasowe w "Nowym Kurierze”: Prezydium policji w Gdańsku, s. 4; Sowiety rozstrzelały, s. 1; a także w „Gazecie Szamotulskiej”: Skazanie na śmierć dwu b. oficerów, s. 2. 
ani o szkołach wywiadu, ani tym bardziej o umiejętnościach tam zdobywanych. Z prasy tamtego okresu niewiele wiadomo o sposobach szkolenia służb specjalnych. W gazetach pojawiały się jednak artykuły uchylające rąbka tajemnicy. Nic nie stało na przeszkodzie, aby pisać o czasach I wojny światowej i ówczesnych metodach przygotowywania wywiadowców do służby. Dowiadywano się zatem o tym, że szkoły były usytuowane w okolicach niezamieszkanych, w budynkach, które nie wzbudzały podejrzeń, niczym nie wyróżniały się od innych, czasem w klasztorach albo opuszczonych szkołach ${ }^{70}$. Przyjmowano kandydata do służby i badano jego inteligencję, odwagę i rzeczywiste nastawienie do spraw ojczyzny, gotowość do poświęcenia się dla niej. Pozytywny wynik sprawdzenia oznaczał przejście do właściwego etapu szkolenia. Każdy z kandydatów posiadał tylko taki zasób wiedzy, który był potrzebny do realizacji powierzonego mu zadania. Gdyby został pojmany przez wroga, nie wyjawiłby nic, co mogłoby w jakikolwiek sposób wpłynąć na bezpieczeństwo pozostałych, wyjawić ich dane albo ujawnić informacje, które naprowadziłyby nieprzyjaciół na oddział wojska. Mężczyźni byli kwaterowani w celach klasztornych. Kurs rozpoczynało pięćdziesięciu. Nauki każdy $\mathrm{z}$ nich pobierał oddzielnie. Rano do pokoju przychodził oficer, dawał uczniowi mapę, informował, jakiej wiedzy potrzebuje, tłumaczył kierunek marszu, a następnego dnia uczeń miał przedstawić szczegółowy raport, w którym obok odpowiedzi na pytania, musiał także podać wiele drobiazgowych informacji. Im bardziej dokładne były informacje, tym lepiej oceniano ucznia. Nauczano oznak armii nieprzyjacielskiej, a także rodzajów broni przez niego wykorzystywanej. Kurs kończył się egzaminem, pisano pracę pt. Jak mam się zachować w kraju nieprzyjacielskim? Do służby kierowano tylko tych, którzy otrzymali ocenę minimum dobrą. Następnie adept wyposażony w fałszywe dokumenty, plany miejsca, w które miał się udać, przystępował do realizacji zadania $^{71}$. Przedstawiony przykład dotyczył szkolenia w wywiadzie rosyjskim w okresie I wojny światowej. Po jej zakończeniu, wspominając o GRU (Razwiedupr) pisano: „Cała akcja szpiegowska sowietów wywiad i kontrwywiad polityczny i wojskowy, zbieranie informacji politycznych i gospodarczych prowadzone są przez »Razwiedupr«, który [...] działa nader konspiracyjnie i stosuje w swej pracy stare doświadczenia sztuki szpiegowskiej"72.

„Stare doświadczenia" stosowane były nie tylko przez rosyjskie służby specjalne, zebrane z zamieszczanych przez dziennikarzy informacji, dawały obraz „narzędzi” wykorzystywanych przez wywiady. Najczęściej zatem pisano o używaniu aparatów fotograficznych, rzadziej zdecydowanie o środkach

\footnotetext{
${ }^{70}$ Kpt. Pekka - as wywiadu rosyjskiego, s. 3.

${ }^{71}$ Tamże.

72 Szpiegowskie nici rządu sowieckiego, s. 2.
} 
usypiających ${ }^{73}$ bądź nietypowych miejscach przechowywania zdobytych dokumentów, planów czy map, takich jak: ustniki papierosów ${ }^{74}$, kieszonki kałowe psów ${ }^{75}$ itp.

Temat szpiegostwa $\mathrm{w}$ prasie wielkopolskiej był niewątpliwie jednym z najczęściej poruszanych w okresie II Rzeczypospolitej. Na jego popularność wpływało nie tylko szerokie zainteresowanie czytelników, chęć poznania przesłoniętego tajemnicami życia szpiegów. Na pewno rozrastający się rynek prasowy i coraz większa konkurencja na nim powodowały, że chęć zdobycia czytelników wymuszała koncentrację na tematach wzbudzających zainteresowanie. To częściowo wyjaśnia zamieszczanie nawet krótkich, a niepozbawionych sensacyjnych wątków informacji o aresztowaniach czy podejrzeniach o szpiegostwo. Poza chęcią zdobywania czytelników była jeszcze kwestia porozumienia albo inspiracji z poznańską „Dwójką”, która, dopuszczając zamieszczanie artykułów o szpiegach i szpiegostwie, prowadziła akcję uświadamiania obywateli o grożącym im niebezpieczeństwie, trudno o przestrogę lepszą dla ewentualnych zdrajców niż wykonywane wyroki śmierci bądź opinia społeczeństwa dążącego do zaostrzenia kar za przestępstwa przeciwko państwu. Informacje o przebiegłych fortelach, o wzbudzających zaufanie agentach obcych wywiadów czy historie działania podczas wojny musiały wywoływać zarówno zaciekawienie, jak rozbudzać umiejętność ochrony tych spraw codziennych, o których wiedza potencjalnego przeciwnika mogłaby być niebezpieczna.

Symbioza prasy i służb specjalnych w okresie dwudziestolecia międzywojennego miała swoje zalety. Korzystali z niej czytelnicy, obywatele, którzy znali z gazet potęgę wywiadów obcych, a także pola ich zainteresowań. Swoje korzyści mieli z niej również redaktorzy naczelni, choć artykuły o szpiegach i szpiegostwie nie były obiektywne ani kompetentne, przyciągały zainteresowanie, wpływały na zyski i wysokość nakładu. Bez wątpienia także polskie służby specjalne realizowały poprzez prasę swoje cele. Edukowanie społeczeństwa było tylko jednym z nich, ważniejsze z perspektywy realizowania operacji było odwrócenie uwagi od przeprowadzanych działań kontrwywiadowczych i kierowanie jej w stronę działalności obcych służb.

\footnotetext{
73 Surowy wyrok za szpiegostwo, s. 2.

74 Szpieg niemiecki schwytany na goracym uczynku, NK, nr 137, z 15 czerwca 1930 r., s. 9.

${ }^{75}$ Kpt. Pekka - as wywiadu rosyjskiego, s. 3.
} 
Patrycja Kanafocka

\title{
Szpiedzy i szpiegostwo w prasie poznańskiej okresu dwudziestolecia międzywojennego
}

\begin{abstract}
Streszczenie
Przedmiotem przedstawianego tekstu jest działalność poznańskiego kontrwywiadu w uświadomieniu zagrożenia szpiegostwem ludności cywilnej na terenie województwa poznańskiego, a także rola, jaką odegrała prasa Poznańskiego w realizacji tego zadania.

Temat szpiegostwa w prasie wielkopolskiej był niewątpliwie jednym z najczęściej poruszanych w okresie II Rzeczypospolitej. Na jego popularność wpływało nie tylko szerokie zainteresowanie czytelników. Rozrastający się rynek prasowy i coraz większa konkurencja na nim powodowały, że konieczność zdobycia uwagi czytelników wymuszała koncentrację na tematach wzbudzających zainteresowanie. Zamieszczano nawet krótkie, a niepozbawione sensacyjnych wątków informacje o aresztowaniach czy podejrzeniach o szpiegostwo. Odrębną zupełnie kwestią była współpraca prasy z poznańską „Dwójką”, która, dopuszczając zamieszczanie artykułów o szpiegach i szpiegostwie, prowadziła akcję uświadamiania obywateli o grożącym im niebezpieczeństwie.

Symbioza prasy i służb specjalnych przyniosła równe korzyści obydwu stronom. Dla prasy zamieszczanie interesujących opinię publiczną informacji przekładało się na liczbę czytelników i nakład, a co za tym idzie także na zysk. Służby specjalne realizowały poprzez prasę swoje cele. Edukowanie społeczeństwa było tylko jednym z nich, ważniejsze z perspektywy realizowania operacji było odwrócenie uwagi od przeprowadzanych działań kontrwywiadowczych i kierowanie jej w stronę działalności obcych służb.
\end{abstract}

\section{Spies and espionage in the Poznań press in the period 1918-1939}

\begin{abstract}
The subject of the article is the operation of counterintelligence in Poznan and its role in raising awareness of the danger of espionage among civilians in the Poznan region, as well as the role of Poznań press in fulfilling this task.

The subject of espionage was undoubtedly one of the most frequently discussed in the Greater Poland press in the period of the Second Polish Republic. The reasons for its popularity lay not only in avid interest it aroused among the readers. The expanding press market and growing competition meant that newspapers had to draw readers' attentions by concentrating on those subjects which the public found interesting. No matter how short the pieces information about the arrests or the suspicion of espionage were, their sensational character meant they were published. The cooperation between the press and the Poznan counterintelligence which, by allowing the press to publish articles on spies and espionage, raised awareness among the citizens on the possible dangers, is a whole separate issue.

The collaboration between the press and special services was mutually beneficial. The press printed articles that were interesting from the point of view of the public, which was then reflected in the number of readers and circulation, as well as financial profit. Special services achieved their own goals. Educating the society was only one of them. From the point of view of their operations, drawing attention away from the activity of counterintelligence and towards the operation of foreign services remained more important.
\end{abstract}

